\title{
Black Lesbian Identities in South Africa: Confronting a History of Denial
}

\author{
Janine E. Carlse ${ }^{1}$
}

\section{Abstract}

Much of the existing literature on South African black lesbian identities has focussed on the prejudice and victimisation that they endure as subjects of homophobia in the form of hate speech and hate crimes, most notably brutal murders and corrective rape. However, not much has been written about the creative ways that black lesbians are fighting against these injustices that are built upon the historical erasure and denial of their very existence in Africa. By outlining three 'denials' of African female same-sex intimacy namely: the imperial denial and subsequent apartheid policing of same-sex intimacy, the denial of female same-sex intimacy through proclaiming it as un-African, and the conceptual denial through the lens of Euro-American feminist lesbian discourse; this article aims to show how black lesbians in South Africa are finding ways to confront these denials. In particular, some aspects of lives and work of selfidentified lesbian activist photographer Zanele Muholi and lesbian sangoma Nkunzi Zandile Nkabinde will be analysed. Muholi and Nkabinde work hard to locate themselves within the public sphere, and engage in projects that aim to educate and build black lesbian communities, in an effort to encourage open dialogue of what it means to be an African lesbian. It can be argued that the voices of South African black lesbians are not only becoming more audible but also more nuanced, where imported notions of sexual identity are being questioned and adapted to their lived realities. Ultimately, this article aims to show how Muholi and Nkabinde provide examples of how reimaginings and negotiations of lesbian identities in (South) Africa are at once complex and essential, and this echoes Msibi's (2014) call for "greater voices from Africa in theorising sexuality - a terrain long ignored in African scholarship."

\section{Introduction}

When compared to the rest of Africa, South Africa may come across as progressive and inclusive in the way that same-sex sexuality is embraced in our constitution (1996) and because of the legal recognition of same-sex marriage (2006). It can be argued, however, that the lived

\footnotetext{
1 Janine Carlse is a $\mathrm{PhD}$ candidate in the Education Policy Studies Department at Stellenbosch University. In 2013 she attained her masters degree in Religious Studies from the University of Cape Town. Her dissertation "Crossing Boundaries: Religion, Sexuality, and Identity in the Lives of Zanele Muholi and Nkunzi Zandile Nkabinde" (University of Cape Town, 2013) has informed the discussion within this article. ORCID iD: https://orcid.org/0000-0001-6377-807X; Email: jecarlse@gmail.com
} 
realities of the majority of black ${ }^{2}$ South African lesbians are far removed from the ideal represented within national legislation. The continuous debate and negotiation that inform the fight for the recognition of black female same-sex sexuality in (South) Africa highlights the way that conceptions of same-sex intimacy are "central to debates about tradition and culture"3 that inform African women's lived realities. Conservative societal attitudes towards sexuality are largely based on broader conceptions of race, class, culture and gender, with the potential to both enable and constrain sexual identities; there is therefore much that can be learned from the cultivation of a "better understanding of the fluid and changing expressions of lesbian and female same-sex sexualities across the African continent." 4

This article aims to make a contribution to this better understanding of (South) African female same-sex sexualities, echoing Msibi's (2014) call for "greater voices from Africa in theorising sexuality - a terrain long ignored in African scholarship." The article has been divided into two parts, the first outlines how the existence of black female same-sex intimacy in (South) Africa has been denied in three persisting ways: the imperial denial and apartheid policing of same-sex intimacy, the denial of female same-sex intimacy through proclaiming it as un-African, and the conceptual denial through the lens of Euro-American feminist lesbian discourse. The second part presents a brief analysis of the lives and work of two South African black lesbians in particular, self-identified lesbian $^{6}$ activist photographer Zanele Muholi and lesbian sangoma Nkunzi Zandile Nkabinde, and the particular strategies that they employ to confront these denials, such as locating themselves within the public sphere, and engaging in projects that aim to educate and build black

\footnotetext{
${ }^{2}$ Although in the post-apartheid context black is used to generally refer to non-white persons (African, Indian, Coloured, etc.), in this article black is specifically used to describe black persons of African heritage.

3 Ruth Morgan and Graeme Reid, "I've Got Two Men and One Woman': Ancestors, Sexuality and Identity among Same-Sex Indentified Women Traditional Healers in South Africa." Culture, Health and Sexuality 5, no. 5 (2003): 377.

${ }^{4}$ Ashley Currier and Therese Migraine-George, "'Lesbian'/female Same-Sex Sexualities in Africa." Journal of Lesbian Studies 21, no. 2 (2017): 133.

5 Thabo Msibi, "Is Current Theorising on Same-Sex Sexuality Relevant to the African Context? Sub-Title: The Need for More African Voices on Theorising Same-Sex Desire in Africa," Pambazuka News (2014).

${ }^{6}$ It is important to note going forward that although I will be problematising the use of term 'lesbian' to describe all female same-sex sexual identities in (South) Africa, because Muholi and Nkabinde openly self-identify themselves as lesbian and emphasize their lesbian identity as African women, borrowing from Euro-American and African frames of reference when making sense of their sexual identity, I will be using the term 'lesbian' when describing their sexuality.
} 
lesbian communities, encouraging acknowledgement and open dialogue of what it means to be an African lesbian.

Muholi and Nkabinde make important contributions to the visual, oral and autobiographical narratives of black lesbian lives, as called for by bell hooks when she advocates for more "oral histories and autobiographies that explore the lives of black gay people in diverse black gay communities" that are essential to understanding what it means to be "black and gay." 7 They have found ways to articulate powerful and creative expressions that fight the silence, erasure and marginalisation that black lesbians face, creating her-story for future generations in the process.

\section{Imperial denial and apartheid policing of same-sex intimacy}

Spanning at least two centuries, African sexuality has been defined and recorded through the imperialist eyes and pens of white men, reinforcing the "ethnocentric and racist construction of African sexualities" emphasizing voyeuristic and "ethnopornographic" 9 views of African people that served to other them from Europeans. This 'othering' of African cultures and sexualities, which labelled them inferior to the West, then served as justification for the colonising regimes of imperialists. ${ }^{10}$ Further, the denial of sexual diversity within African cultures due to European religious heteronormative frames of reference, have both racist and homophobic undertones. Thabo Msibi notes that "it was European ethnographers who first declared that homosexuality was unAfrican, arguing that Africa was a sodomy-free zone." ${ }^{11}$ This Christiancentric reasoning allowed European conceptions of 'right' (hetero) sexuality to infiltrate African thought, ${ }^{12}$ and this framing of same-sex intimacy as a perversion that flies in the face of Christian morality still features prominently within contemporary homophobic discourse.

\footnotetext{
${ }^{7}$ bell hooks, "Homophobia in Black Communities," in The Greatest Taboo: Homosexuality in Black Communities, ed. Delroy Constantine-Simms (Los Angeles and New York: Alyson Books, 2000), 69.

${ }^{8}$ Sylvia Tamale, "Researching and Theorising Sexualities in Africa." In African Sexualities: A Reader. Pambazuka Press, 2011, 15.

${ }^{9}$ Tamale, "Researching and Theorising Sexualities in Africa", 19.

${ }^{10}$ Janine Carlse, "Crossing Boundaries: Religion, Sexuality, and Identity in the Lives of Zanele Muholi and Nkunzi Zandile Nkabinde." Unpublished Masters Thesis (2013), 64.

11 Thabo Msibi, "The Lies We Have Been Told: On (Homo) Sexuality in Africa," Africa Today 58, no. 1 (2011): 63.

12 Graeme Reid and Liz Walker, "Sex and Secrecy: A Focus on African Sexualities," Culture, Health and Sexuality 7, no. 3 (2005): 186.
} 
In South Africa in particular, the imperial denial of African same-sex intimacy was later institutionalised by the laws of apartheid spanning nearly half a century. These laws systemically discriminated against nonwhite people in all facets of their lives. The control of peoples' sexual practices under apartheid was just one way that the racist Afrikaner nationalist ideologies were systemically ingrained in the collective consciousness of South Africans. Discriminatory laws included the Immorality Act of 1957, and Section 20A of the Sexual Offences Act of 1957 that "made it a criminal offence for men to engage in consensual sexual conduct with other men." ${ }^{13}$ Twenty years later, in 1977, the inclusion of sodomy as a common law offence would allow for the arrest of any male suspected of this crime under "Schedule I of the Criminal Procedure Act of $1977 . " 14$

While the sodomy laws were particularly directed at men, black women's oppression under the regime of apartheid was manifold. Apartheid laws and policies kept African black women publicly invisible. Writing at the beginning of the last decade of apartheid, Poinsette states that "Black women's lives provide a clear picture of the brutality of apartheid, as the statutory controls that implement the system often affect women more harshly than men." ${ }^{15}$ Poinsette further elaborates on the mandate of the regime, noting that "The 'Grand Design' of apartheid has two primary goals. The first is to expel Blacks from the nation of South Africa; the second is to ensure that Blacks remain available to perform the labour needed to fuel the economy."16 Many black women therefore sacrificed fighting for their gendered and sexual identities to prioritise participation in anti-apartheid movements against widespread exploitation, discrimination and dehumanisation. In this regard it can be argued that "black lesbians in many ways experience a double oppression, one from patriarchy and heteronormativity, and one from their location in the history of South Africa as black women." ${ }^{17}$ Yet many black female activists are following in the footsteps of apartheid activists "such as Charlotte Maxexe and the women of the pass campaigns - to [...]

\footnotetext{
${ }^{13}$ Wendy Isaack and Melanie Judge, "Ten Years of Freedom? Current Developments and Debates on Marriage between People of the Same Sex in South Africa," Agenda 18, no. 62 (2004): 70.

${ }^{14}$ Isaack and Judge, "Ten Years of Freedom?", 70.

${ }^{15}$ Cheryl L. Poinsette, "Black Women under Apartheid: An Introduction," Harvard Women's Law Journal 8 (1985): 93.

${ }^{16}$ Poinsette, "Black Women under Apartheid", 118.

${ }^{17}$ Carlse, "Crossing Boundaries", 121.
} 
activists such as Winnie Mandela and the women of Crossroads"18 who fought for societal change and liberation.

\section{The denial of female same-sex intimacy through proclaiming it as un-African}

Due to the lasting legacy of the discriminatory apartheid regime, even within the current post-apartheid state, the socio-economic circumstances that the vast majority of the South African black population find themselves currently living in (and protesting against) can be attributed to the deeply ingrained systemic injustices that have characterised the history of South Africa. Against the backdrop of this dehumanising history, prejudices within the black community against 'new' identities such as that of 'black lesbian' adds another layer of complexity to the social landscape. Many black lesbians find themselves living within vast urban townships such as Soweto and Khayelitsha, ${ }^{19}$ and it is within these settings that the threat of female same-sex sexualities is, perhaps, most evident through the perpetration of hate crimes. Within the communal and integrated spaces of the township, public black female same-sex sexual identities threaten accepted heteronormative (and patriarchal) conceptions of black masculinity (and femininity). ${ }^{20}$ In addition to this, the ongoing rhetoric by public political and religious figures that female same-sex sexuality is 'un-African' reinforces the fear and prejudice that encourages homophobia and the victimisation of 'black lesbians'.

Thabo Msibi argues that "the wave of human rights that has swept through Africa has permitted many to claim "gay" identity" and this has in turn aggravated the "already heightened fear of the 'anxious' man." ${ }^{21}$ In the abstract to his article "The Lies We have Been Told", Msibi asserts

\footnotetext{
${ }^{18}$ Poinsette, "Black Women under Apartheid", 119.

${ }^{19}$ In South Africa it is estimated that 7 million people (about $12.5 \%$ of the population) live in overcrowded and poorly serviced urban townships, with the numbers growing each year. These townships are black 'neighbourhoods' mostly consisting of informal settlements, and are a repercussion of forced socio-economic segregation during apartheid coupled with mass migration from rural to urban areas in the search for employment opportunities (in the first quarter of 2018, South Africa's unemployment rate was $26.7 \%$ ).

${ }^{20}$ Zethu Matebeni, "Tracks: researching sexualities walking about the city of Johannesburg." In African Sexualities: A Reader. Pambazuka Press, 2011: 50-56.

Matebeni recounts Soweto-born black lesbian activist and film-maker, Bev Palesa Ditsie's experience in 1990 after appearing on television speaking at the first Pride March in Johannesburg: "She was unable to be a lesbian in her own neighbourhood and, whenever noticed, men believed she should be 'put right' by being shown that she was a woman or removed altogether from the black neighbourhood. Threats of sexual assault and violence were directed towards her." (51).

${ }^{21}$ Msibi, "The Lies We Have Been Told", 55-56.
} 
that "homophobia is not only publicly approved by African leaders, but relies on unsubstantiated claims of an imposed homosexual identity, contradictory ideas on morality, and the use of outdated laws." ${ }^{22}$ Msibi's article aims to show that the key difference between the perceived EuroAmerican imposition of homosexuality and African understandings of same-sex intimacy is its social construction. ${ }^{23}$ According to Currier and Migraine-George, the social construction of African same-sex intimacy has been shaped by the availability of "homosocial spaces of intimacy"24 that exist as part of the social fabric of diverse cultural and religious communities. Female same-sex relationships, in whatever form, are enacted within these secretive yet normative homosocial spaces that accommodate these engagements. While the homosocial spaces accommodate same-sex intimacy, these personal and private spaces also play a role in reinforcing "understandings of female same-sex sexualities as taboo." ${ }^{25}$

It is not surprising that in contrast to the secrecy that characterises female homosocial spaces, Euro-American ideals of public sexuality and the act of 'coming out' presents what can easily be framed as 'unAfrican'. ${ }^{26}$ Msibi further argues that "the renewed efforts to label samesex desire as un-African represents a façade that conceals neoconservatism and a resurgence of patriarchy, coated in the constructs of religion, nationalism, and law." ${ }^{27}$ Currier and MigraineGeorge echo Msibi's sentiment that the rhetoric of "homosexuality-is-unAfrican" has permeated African political and religious leaders' nationalist and "anti-Western" discourses promoting same-sex sexuality as "a mere decadent Western import". ${ }^{28}$ Furthermore, Matebeni (2013) labels this "claim that black queerness colludes with whiteness" as irrational, in that it works to construct "same-sex couples and intimacy as monoracial."29 So ultimately, in "shifting the attention to queer identity's association with whiteness," the interrogation of patriarchal and heteronormative power dynamics within blackness is avoided. ${ }^{30}$

\footnotetext{
${ }^{22}$ Msibi, "The Lies We Have Been Told", 55.

${ }^{23}$ Msibi, "The Lies We Have Been Told", 55.

${ }^{24}$ Currier and Migraine-George, "'Lesbian'/Female Same-Sex Sexualities in Africa", 137.

${ }^{25}$ Currier and Migraine-George, "'Lesbian'/Female Same-Sex Sexualities in Africa", 140.

${ }^{26}$ This is not to say that there aren't Euro-American anti-gay communities, organisations, and sentiments.

${ }^{27}$ Msibi, "The Lies We Have Been Told", 55.

${ }^{28}$ Currier and Migraine-George, "'Lesbian'/Female Same-Sex Sexualities in Africa”, 142.

${ }^{29}$ Zethu Matebeni, "Intimacy, Queerness, Race." Cultural Studies, 27: 3 (2013), 410.

${ }^{30}$ Matebeni, "Intimacy, Queerness, Race," 410.
} 
In addition, this "decadent Western import" has been promoted as a threat to what are understood to be ingrained cultural and religious masculinities as enacted by political and cultural leaders that claim to embody 'true' African masculinity. However, these conceptions of true masculinity are also tightly bound up in (patriarchal) conceptions of 'true' femininity, which in turn inform hierarchies of power. Notions of true (heterosexual) femininity have long been promoted in Africa through Western Christianity as imposed by the colonial missionaries in the past and conservative religious organisations in the present, discouraging 'deviant' sexual behaviour (from homosexuality to abortion) and incentivising 'good' sexual and reproductive choices (such as marriage and motherhood). Non-heterosexual identities therefore encourage a questioning of normative power relations and pose a threat to patriarchal and conservative cultural beliefs.

Conceptions of 'true African masculinity' are not just defended and reinforced by men, but by women as well. This sentiment can be found in women's movements, where lesbian rights may not be advocated for as women's rights if they seem to be in opposition to more widely accepted identities. Currier and Migraine-George quote Marx Ferree's and McClurg Mueller's (2004) definition of women's movements as "mobilizations based on appeals to women as a constituency" as opposed to feminist movements that advocate for advancing the "goal of challenging and changing women's subordination to men." ${ }^{31}$ The political (and often religious) alignment of women's movements in Africa pose certain limitations on the framing of lesbian rights as women's rights, as lesbian identity is generally considered contradictory to conceptions of 'true African femininity'. Therefore if lesbian rights are included in women's rights, political and religious authorities can disavow African "women's rights advocates as national, cultural, and even sexual traitors." 32 For example, the African National Congress (ANC) Women's League in South Africa openly supported, the then Vice-president, Jacob Zuma during his publicised rape trial in 2006. During the trial, Zuma and his defence appealed to traditional notions of Zulu culture and masculinity to justify Zuma's actions and simultaneously place a shadow over the accuser's (known as Khwezi) character. ${ }^{33}$ Zuma was acquitted of all charges of rape, and Khwezi - an HIV positive lesbian woman -

\footnotetext{
${ }^{31}$ Currier and Migraine-George, "'Lesbian'/Female Same-Sex Sexualities in Africa”, 141.

${ }^{32}$ Currier and Migraine-George, "'Lesbian'/Female Same-Sex Sexualities in Africa", 141.

${ }^{33}$ Steven Robins, "Sexual Politics and the Zuma Rape Trial," Journal of Southern African Studies 34, no. 2 (2008), 411-427.
} 
was forced into seek asylum in the Netherlands due to the harassment she faced from Zuma supporters. ${ }^{34}$

Rhetoric that promotes patriarchal conceptions of masculinity while proclaiming female same-sex intimacies as un-African therefore reinforce the denial and silencing of these same-sex relationships and their many incarnations throughout the African continent. This promotes conservative attitudes toward sexuality that reinforce homophobic attitudes, encouraging the policing and oppression of already marginalised sexual identities that have traditionally been shrouded in secrecy. The reimagining and repositioning of black female same-sex sexuality in the public imagination is therefore not without its tensions.

\section{Conceptual denial through the lens of Euro-American feminist lesbian discourse}

The terms 'homosexual' and 'gay' have their roots within a specific cultural history that is not African, but squarely Euro-American (Western). The study of sexuality in itself has mostly been from "EuroAmerica" or "academic neoimperialist" perspectives. ${ }^{35}$ According to Msibi, homosexuality was "a term initially introduced in the West to control social relations, while labelling those engaged in same-sex relations as deviant," while gay "is a political identity, which comes from Western struggles for civil rights in the 1960s." ${ }^{36}$ Therefore, more diverse and nuanced representations and conversations about same-sex sexualities are needed as alternatives to these homogenous notions of 'gay' and 'homosexual' that have been transposed into various contexts.

As emphasised by Matebeni and Msibi (2015), "destabilising the normative standards that are used to limit how we speak and name ourselves is a necessary eruption." ${ }^{37}$ The twenty-first century therefore calls for alternative dialogues and imaginings that affirm rather than deny the various forms that African female same-sex intimacies may take. Euro-American constructs of female same-sex sexuality are often framed in opposition to heterosexuality or within gender binaries. These limited conceptions of sexuality can be restrictive within the African context where notions of 'becoming' and the fluidity of social roles are

\footnotetext{
${ }^{34}$ Khwezi (Fezeka Kuzwayo), a self-identified lesbian, passed away in 2016 at the age of 42. She was the daughter of veteran Judson Kuzwayo who served a prison term with Jacob Zuma on Robben Island during apartheid and regarded Zuma a close family friend.

${ }^{35}$ Currier and Migraine-George, "'Lesbian'/Female Same-Sex Sexualities in Africa”, 134.

${ }^{36}$ Msibi, "The Lies We Have Been Told", 56.

${ }^{37}$ Zethu Matebeni and Thabo Msibi. "Vocabularies of the non-normative." Agenda, 29: 1 (2015), 5.
} 
commonplace. It can be argued that the now 'normative' imported description of female same-sex intimacy as 'lesbian' has therefore added to the marginalisation of indigenous forms of female same-sex intimacy, and the violent policing of public 'lesbian' sexual identities in (South) Africa. $^{38}$ In addition to this, within conservative communities, if not approached in a sensitive manner, imposing Euro-American liberal norms of 'coming-out' and positioning oneself in the public sphere could put "queer women's bodies in particular risk [of] further objectification, erasure, and the violation of their human rights."

There is a need to interrogate these conceptions of gender and sexuality when trying to characterise or articulate same-sex intimacy in Africa. This interrogation can be achieved if same-sex "interactions, relationships, and politics between African women" garner more attention in African, feminist and queer studies to address its under representation in academic writing. ${ }^{40}$ Showing the "relational, contextual and embodied ways in which everyday sexuality is negotiated," ${ }^{41}$ in light of the call for a contemporary 'Africanisation' of gender discourse, may forge the beginnings of a reimagining of gender and sexuality for African women that do not view themselves as fitting within the confines of Western conceptions of lesbianism. The 'secrecy' or 'silence' that may be viewed as negative within Euro-American paradigms of sexuality, have also made female same-sex intimacy in Africa possible for centuries, so one cannot ignore the cultural contexts within which same-sex loving women locate themselves. Definitions of sexuality can therefore not be imported wholesale, and the visibility of alternative depictions and realities are important as this could foster the identity formation of black lesbians, providing role-models and voices to those who may have previously felt voiceless or dehumanised.

\section{Visual voice - Zanele Muholi}

I take photographs to remember those who cannot speak freely and to be remembered. I believe photography to be my first language, a calling that I received from my ancestors so that I could voice my issues and concerns. Whatever I have captured and still capture is for

\footnotetext{
${ }^{38}$ Carlse, "Crossing Boundaries", 121.

${ }^{39}$ Currier and Migraine-George, "'Lesbian'/female Same-Sex Sexualities in Africa”, 144.

${ }^{40}$ Currier and Migraine-George, "'Lesbian'/female Same-Sex Sexualities in Africa”, 134.

${ }^{41}$ Matebeni and Msibi, "Vocabularies of the non-normative," 7.
} 
the world to see that we exist as black lesbians, women, trans men, intersexed, bisexuals, trans women - as queer Africans. ${ }^{42}$

Acclaimed photographer and activist, Zanele Muholi, uses the medium of photography to provide an insight into the "life choices, decisions, failures, confusions, discoveries, rejections" ${ }^{43}$ of (South) African black lesbians. Muholi appropriates photography as a means for creative expression, while simultaneously reclaiming the medium from its traditionally male-dominated and exploitative use as a means of 'capturing' the black (female) body. Muholi's photography has become a public vehicle through which to advocate and create a voice for the (South) African black lesbian community, acting as a "radical survival strategy in the post-apartheid order," fighting against conceptions of same-sex intimacy as unnatural and un-African. Through working within the genre of documentary photography, Muholi is able to provide political commentary that is at once personal and political, creating awareness while also attempting to educate the public about the lived realities of black lesbians (and non-heterosexual Africans more broadly). Her international exposure as an artist and activist, exhibiting numerous collections in renowned galleries around the world, has earned Muholi a prominent place within the international art community. It can be argued that Muholi's work is more accepted and admired abroad than it is in South Africa, an indication of the country's deeply seated conservative attitudes towards the visibility of black female same-sex sexuality.

These conservative attitudes towards Muholi's photography have shown up in striking ways throughout her career. One being Lulu Xingwana's ${ }^{45}$ publicised reaction to Muholi's work at the Innovative Women exhibition in 2010, and another being the theft of five of Muholi's hard drives from her home in 2012. In 2010, Xingwana labelled Muholi's work depicting nude black women embracing one another as 'immoral', 'pornographic' and 'against nation building'; ${ }^{46}$ while in 2012 the thieves who stole Muholi's hard drives containing much of her life's work documenting lesbian lives in Africa had no interest in stealing anything else from her apartment in Cape Town. $^{47}$ These are just two incidents that demonstrate the personal and professional attacks that individual African

\footnotetext{
${ }^{42}$ Zanele Muholi, "I have truly lost a woman I loved." In Reclaiming the L-Word: Sappho's Daughters Out in Africa, edited by Aleyn Diesel. Modjaji Books (2011), 11-25.

${ }^{43}$ Gqola, "Through Zanele Muholi's Eyes: Re/lmagining Ways of Seeing Black Lesbians," 84.

${ }^{44}$ Matebeni, "Intimacy, Queerness, Race," 410.

${ }^{45}$ Xingwana was South Africa's Minister of Arts and Culture at the time.

${ }^{46}$ Carlse, "Crossing Boundaries", 6.

${ }^{47}$ Carlse, "Crossing Boundaries", 117.
} 
feminists or activists who support lesbian rights experience. However, these incidents also show the dire need for Muholi's advocacy within this societal context, fighting for the dignity and acceptance of African women who do not identify as heterosexual.

The inspiration for Muholi's Being series (2007), which came under criticism at the Innovative Women exhibition in 2010, came from wanting "to create a body of meaning that is welcomed by us as a community of queer black women." ${ }^{48}$ Muholi acknowledges all the subjects she photographs as participants within the process and is careful not to add to the further objectification of black women's bodies that have been commonplace within the history of documentary photography. It is also important for Muholi to show the positive, and often hidden, intimate and erotic aspects of black lesbian lives, providing an alternative to the narratives that prioritise their victimisation. ${ }^{49}$ Through her promotion of the positive representation of black female sexual identities, and actively forming networks and communities, Muholi is disrupting dominant cultural and societal norms of secrecy that perpetually keep black lesbians isolated and marginalized or make them 'hypervisible' (and prone to policing) when they do step out of the private realm. So although Muholi's work borrows from Euro-American strategies of making sense of female same-sex sexuality, it is still effective as a graphic "tool that speaks, works, challenges and liberates." 50 She also inspires questioning and makes use of African frames of reference that encourage an acknowledgement of the cultural identities and histories of the people that she photographs (including herself).

\section{Narrative voice - Nkunzi Zandile Nkabinde}

Each of my different roles, as a Zulu woman, as a lesbian and a sangoma, comes with its own challenges. Working at Constitution Hill gives me a high view. I can stand with my back to our apartheid history which is still alive in the Old Fort and the Women's Prison and see the Constitutional Court and be reminded of all that is good in our country; and I can stand on top of the hill outside the Constitutional Court and get an overview of Johannesburg. I can see the good and the bad of

${ }^{48}$ Zanele Muholi, Mapping our Histories: A Visual History of Black Lesbians in PostApartheid South Africa, www.zanelemuholi.com (2009), Date Retrieved 05/10/2010.

${ }^{49}$ Matebeni, "Intimacy, Queerness, Race," 414.

${ }^{50}$ Matebeni, "Intimacy, Queerness, Race," 414. 
the city. This is what I try to do when I think about my own life. I try to take a look from a high place and see the good and the bad. ${ }^{51}$

Nkunzi Zandile Nkabinde is a Zulu lesbian sangoma, in 2009 she published an autobiography - Black Bull, Ancestors and Me: My Life as a Lesbian Sangoma - outlining her life's journey up to that point, how she creatively negotiated her personal experiences, cultural beliefs and religious calling with her sexuality. Nkabinde is open about the many dimensions of her life, and how her cultural and religious beliefs enable and, at times, constrain her sexual identity. Through the medium of autobiography, Nkabinde has chosen to affirm (rather than deny) the existence of female same-sex intimacy in Africa in a way that invites open dialogue and the interrogation of taken for granted assumptions about African culture.

Nkabinde's self-dentification as a 'lesbian sangoma' places her within a liminal space that comes with placing these two concepts side by side, facilitating a constant conversation between contemporary feminist discourse and traditional cosmological beliefs. ${ }^{52}$ The institution of sangoma within Zulu culture has its own complexity, even before being associated with Euro-American frames of reference that have defined what it means to be 'lesbian'. Female sangomas, like Nkabinde, have a strong affiliation with their dominant male ancestor, and this is evident in the way that Nkabinde identifies herself first by Nkunzi (her dominant male ancestor's name) and acknowledges the influence that he has over her sexual choices (that include choosing an ancestral wife). ${ }^{53}$ Nkabinde simultaneously sees herself as a vessel for her ancestors and as an autonomous being with the agency to make her own decisions. However, the public manner in which Nkabinde chooses to express her sexual identity is not without its challenges from elders within her sangoma community demanding that she keep her lesbian sexuality and relationships secret "because lesbians are not part of African life." ${ }^{54}$ So while Nkabinde's same-sex sexuality is in a sense protected and governed through the cultural role as a sangoma within her community, the agency that she shows in enunciating her positionality as a Zulu 'lesbian' sangoma adds a layer of novelty and scepticism.

\footnotetext{
${ }^{51}$ Nkunzi Zandile Nkabinde, Black Bull, Ancestors and Me: My Life as a Lesbian Sangoma. Fanele: an imprint of Jacana Media (2009).

${ }^{52}$ Carlse, "Crossing Boundaries", 54.

${ }^{53}$ Nkabinde, Black Bull, Ancestors and Me, 67-76.

${ }^{54}$ Nkabinde, Black Bull, Ancestors and Me, 121.
} 
In the chapter entitled "In Search of Community," ${ }^{55}$ Nkabinde outlines her involvement with Ruth Morgan at the Gay and Lesbian Archives (GALA now known as Gay and Lesbian Memory in Action), ${ }^{56}$ and how this educated her about the history of same-sex intimacy in Africa and her positionality as a lesbian sangoma. Nkabinde's work at GALA as a researcher and tour guide also encouraged her to autobiographically document her own experiences. As a tour guide at Constitution Hill and on the GALA Queer Tour ${ }^{57}$ from Johannesburg to Soweto, Nkabinde participated in consciousness raising about the role that the lesbian and gay community played during the struggle against apartheid. As a researcher, Nkabinde also played an important part in projects that focused on finding and interviewing non-heterosexual sangomas and setting up networks for them. One of the projects that Nkabinde highlights in her book is initiating the "Sangomas Coming Out" group in 2002 with ten gay and lesbian sangomas from the Gauteng province, and within six months Nkabinde had interviewed over thirty sangomas, discovering that she was part of a broader community that spanned the whole of South Africa while also adding to the much needed scholarship on the subject by publishing her findings in a book chapter with Ruth Morgan (then director of GALA). ${ }^{58}$

\section{The importance of alternative African voices and imaginings in the fight against the denial of black female same-sex sexuality}

Many lesbian rights activists are using "alternative forms of media like photography, digital stories, and documentary filmmaking to represent

\footnotetext{
${ }^{55}$ Nkabinde, Black Bull, Ancestors and Me, 77-120.

${ }^{56}$ More information about the work the GALA does in South Africa can be found on their website: http://gala.co.za

${ }^{57}$ As outlined in Matebeni in "TRACKS: researching sexualities walking abOUT the city of Johannesburg," 52: "Through a very extensive mapping process, the tour captures all of gay Johannesburg's famous landmarks, such as the Harrison Reef Hotel in Hillbrow (a notorious area in the inner city), the oldest gay bar and home to the first gay and lesbian church for black people; Forest Town, an affluent northern suburb where a gay party was raided by police in 1966, leading to the implementation of harsh measures aimed at stamping out homosexuality; Simon Nkoli Corner in Hillbrow, dedicated to the memory of the gay anti-apartheid and AIDS activist, who was tried for treason; Constitution Hill, a former prison and now the home of South Africa's constitutional court and of two lesbian and gay organisations; and the Soweto homes and spaces of gay and lesbian activists."

${ }^{58}$ Nkunzi Nkabinde and Ruth Morgan, "Chapter Seven." In Tommy Boys, lesbian men and ancestral wives: female same-sex practices in Africa, edited by Ruth Morgan and Saskia Wieringa. Jacana Media (2005), 231-260.
} 
the complexities of Black lesbian lives in post-apartheid South Africa." The lives and work of activist photographer Zanele Muholi and lesbian sangoma Nkunzi Zandile Nkabinde provide examples of the way that these alternative forms of media are being used imaginatively to relay their personal experiences and the diversity of the black 'lesbian' community. Both Muholi and Nkabinde understand the path that they have chosen as a calling from the ancestors, showing strong links to their cultural roots, while also positioning themselves within previously male dominated spheres - photography and autobiography - inspiring new imaginings of black lesbian narratives and lives.

Muholi and Nkabinde present an amalgamation of indigenous and globalised worldviews, with negotiations of their sexual identities showing the tensions between "two very different ways of dealing with homosexuality, the traditional approach, which finds ways of accommodating it and not talking about it, and the modern, 'Western' way, which claims for homosexuals a public "gay' identity." 60 Because the notion of an African black lesbian identity is in itself complex, requiring negotiations between indigenous and Euro-American conceptualisations of same-sex intimacy, there are few 'black lesbian' role models who encourage these negotiations and imaginings, of what being a black lesbian in Africa could encompass. ${ }^{61}$

Fighting against homogenous representations of African sexuality and the female body, Muholi and Nkabinde provide examples of successful and imaginative negotiations of female same-sex identities. Although they speak about the negative along with the positive, they do not just paint a picture of victimisation but rather aim to empower black lesbians, and also encourage them to empower themselves. There is a need for these positive yet nuanced articulations and representations of black female same-sex relationships and intimacy. This has the potential to encourage black lesbians to articulate their own experiences, and not rely on "outsiders" to do this for them. These articulations do not have to be as public as those of Muholi and Nkabinde, but could be a stepping stone towards transformative dialogues of what it means to be a black queer South African woman in the twenty-first century, and thus reclaim identities and voices that have been historically denied and silenced.

\footnotetext{
${ }^{59}$ Lewis, "Queering Vulnerability : Visualizing Black Lesbian Desire in Post-Apartheid South Africa," 207.

60 Gevisser (1999: 963), as cited in Morgan and Reid, "I've Got Two Men and One Woman," 377.

${ }^{61}$ Carlse, "Crossing Boundaries", 103.
} 


\section{Conclusion}

Through first outlining the complexity of the multi-layered denials of (South) African female-same sex intimacy, this article gave some insight into the forces that African black lesbians have, and still, confront in their daily lives. Black lesbian lives in South Africa continue to be influenced by the intersections of African and global discourses on sexuality. What is clear is that there is no one-size-fits-all within this negotiation of sexuality, there is fluidity and diversity, and each woman should be allowed to negotiate her sexuality in her own way, and for the most part "current Western theorising fails to capture accurately the structural, cultural, historical and societal complexities found in the African context." ${ }^{62}$ By locating themselves within the public sphere, engaging in projects that aim to create awareness and form black lesbian communities - placing emphasis on educating lesbians about their history in (South) Africa, and attempting to create a her-story for future generations - Muholi and Nkabinde encourage a contemporary African imagining of female same-sex sexualities.

The ways that Zanele Muholi and Nkunzi Zandile Nkabinde are contributing toward a foundation of what could become an articulate body of work embodies the fight against the historical denial of female same-sex intimacy in Africa that "is integral in the creation of a lasting identity, something for future generations of lesbians to relate to and learn from." ${ }^{\text {"3 }}$ Much like black women during apartheid, black lesbians are finding the resources to combat this dehumanisation. Muholi's and Nkabinde's lives and work reflect the sometimes paradoxical relations between culture, gender and sexuality, acknowledging the power of individual and collective agency within these negotiations. Ultimately, what Muholi and Nkabinde offer in the fight against the denial of African female same-sex sexuality is their affirmation of African lesbians' personal stories that "confirm the diversity and humanity of same-sex loving women's experiences without necessarily reverting to lurid images depicting African lesbians only as victims of homophobic violence." ${ }^{64}$ They transgress binaries in imaginative and thoughtful ways, providing the black lesbian community with new frames of reference that acknowledge their dignity, and from which to envision themselves within the (South) African context. ${ }^{65}$

\footnotetext{
62 Msibi, "Is Current Theorising on Same-Sex Sexuality Relevant to the African Context?"

${ }^{63}$ Carlse, "Crossing Boundaries", 119.

${ }^{64}$ Currier and Migraine-George, "'Lesbian'/Female Same-Sex Sexualities in Africa”, 135.

${ }^{65}$ l'd like to thank the reviewers for their thoughtful consideration of my manuscript. l'd like to acknowledge my masters supervisors Sadiyya Shaikh and David Chidester for their guidance during the study that has acted as a springboard for this article. I'd also like to
} 


\section{Bibliography}

Carlse, Janine. "Crossing Boundaries: Religion, Sexuality, and Identity in the Lives of Zanele Muholi and Nkunzi Zandile Nkabinde." Unpublished Masters Thesis, University of Cape Town, 2013.

Currier, Ashley, and Thérèse Migraine-George. "'Lesbian'/female SameSex Sexualities in Africa." Journal of Lesbian Studies 21, no. 2 (2017): 133-50. https://doi.org/10.1080/10894160.2016.1146031

Gqola, Pumla Dineo. "Through Zanele Muholi's Eyes: Re/Imagining Ways of Seeing Black Lesbians." In Only Half the Picture, Zanele Muholi, edited by Sophie Perryer, 82-89. Cape Town: Michael Stevenson/STE: Cape Town, 2006.

hooks, bell. "Homophobia in Black Communities" In The Greatest Taboo: Homosexuality in Black Communities, edited by Delroy Constantine-Simms. Los Angeles and New York: Alyson Books, 2000.

Isaack, Wendy, and Melanie Judge. "Ten Years of Freedom? Current Developments and Debates on Marriage between People of the Same Sex in South Africa." Agenda 18, no. 62 (2004): 68-75. https://doi.org/10.1080/10130950.2004.9676203

Lewis, Rachel A. "Queering Vulnerability : Visualizing Black Lesbian Desire in Post-Apartheid South Africa." Feminist Formations 28, no. 1 (2016): 205-34.

Matebeni, Zethu. "Intimacy, Queerness, Race”. Cultural Studies, 27: 3 (2013), 404-417.

Matebeni, Zethu. "TRACKS: researching sexualities walking abOUT the city of Johannesburg." In African Sexualities: A Reader. Pambazuka Press, 2011: 50-56.

Matebeni, Zethu and Thabo Msibi. "Vocabularies of the non-normative". Agenda, 29: 1 (2015), 3-9.

Morgan, Ruth, and Graeme Reid. "I've Got Two Men and One Woman': Ancestors, Sexuality and Identity among Same-Sex Indentified 
Women Traditional Healers in South Africa." Culture, Health and Sexuality 5, no. 5 (2003): 375-91.

https://doi.org/10.1080/1369105011000064146

Msibi, Thabo. "Is Current Theorising on Same-Sex Sexuality Relevant to the African Context? Sub-Title: The Need for More African Voices on Theorising Same-Sex Desire in Africa." Pambazuka News, 2014. https://www.pambazuka.org/printpdf/88257

Msiibi, Thabo. "The Lies We Have Been Told: On (Homo) Sexuality in Africa." Africa Today 58, no. 1 (2011): 55-77

Muholi, Zanele. Mapping our Histories: A Visual History of Black Lesbians in Post-Apartheid South Africa, www.zanelemuholi.com (2009), Date Retrieved 05/10/2010.

Muholi, Zanele. "I have truly lost a woman I love.," In Reclaiming the LWord: Sappho's Daughters Out in Africa, edited by Aleyn Diesel. Modjaji Books (2011), 11-25.

Nkabinde, Nkunzi and Morgan, Ruth. "Chapter Seven." In Tommy Boys, lesbian men and ancestral wives: female same-sex practices in Africa, edited by Ruth Morgan and Saskia Wieringa. Jacana Media (2005), 231-260.

Nkabinde, Nkunzi Zandile. Black Bull, Ancestors and Me: My Life as a Lesbian Sangoma. Fanele: an imprint of Jacana Media (2009).

Poinsette, Cheryl L. "Black Women under Apartheid: An Introduction." Harvard Women's Law Journal 8 (1985): 93-119. https://doi.org/10.3868/s050-004-015-0003-8

Reid, Graeme, and Liz Walker. "Sex and Secrecy: A Focus on African Sexualities." Culture, Health and Sexuality 7, no. 3 (2005): 18594. https://doi.org/10.1080/13691050412331334353

Robins, Steven. "Sexual Politics and the Zuma Rape Trial," Journal of Southern African Studies 34, no. 2 (2008), 411-427.

Tamale, Sylvia. "Researching and Theorising Sexualities in Africa" In African Sexualities: A Reader. Pambazuka Press, 2011. 